\title{
Is Screening of TORCH Worthwhile in Women with Bad Obstetric History: An Observation from Eastern Nepal
}

\author{
Namrata Kumari', Norman Morris ${ }^{2}$, and Renu Dutta ${ }^{3}$ \\ 'Department of Microbiology, Indira Gandhi Institute of Medical Sciences, Patna, Bihar, India, ${ }^{2}$ Department of Obstetrics and \\ Gynaecology and ${ }^{3}$ Department of Microbiology, B.P. Koirala Institute of Health Sciences, Dharan, Nepal
}

\begin{abstract}
This pilot case-control study at a tertiary-care hospital over a four-month period was aimed at evaluating the possible usefulness of screening of TORCH (Toxoplasma gondii, rubella virus, cytomegalovirus, and Herpes simplex virus) in females with bad obstetric history. The study included 12 women with bad obstetric history and a similar number of matched controls with previous normal pregnancies. A serological evaluation of TORCH infections was carried out by detecting IgG and IgM antibodies against these infections by ELISA test-kit. Statistical analysis was not done to compare the results relating to the two groups due to a small number of cases and controls included in the study. Ten (83.3\%) of the 12 cases with bad obstetric history and two (16.7\%) of the 12 healthy controls were serologically positive at least for one of the TORCH agents. The seropositivity rate in women with bad obstetric history was quite high compared to that in the normal healthy controls. The results suggest that a previous history of pregnancy wastage and the serological evaluation of TORCH infections during current pregnancy must be considered while managing cases with bad obstetric history.
\end{abstract}

Key words: Bad obstetric history; Case-control studies; TORCH screening; Nepal

\section{INTRODUCTION}

Bad obstetric history (BOH) implies previous unfavourable foetal outcome in terms of two or more consecutive spontaneous abortions, history of intrauterine foetal death, intrauterine growth retardation, stillbirth, early neonatal death and/or congenital anomalies. Cause of BOH may be genetic, hormonal, abnormal maternal immune response, and maternal infection (1). Primary infections caused by TORCH-Toxoplasma gondii, rubella virus, cytomegalovirus (CMV), and Herpes simplex virus (HSV) - is the major cause of $\mathrm{BOH}(2)$.

The prevalence of these infections varies from one geographical area to another (3). These maternal infections are initially unapparent or asympto-

Correspondence and reprint requests should be addressed to:

Dr. Namrata Kumari

Assistant Professor

Department of Microbiology

Indira Gandhi Institute of Medical Sciences

Campus

D3/4 Sheikhpura, Patna 14, Bihar

India

Email:irainrai@yahoo.co.in

Fax: 0612-2297225 matic and are, thus, difficult to diagnose on clinical grounds $(4,5)$. Therefore, diagnosis of acute TORCH infection in pregnant women is usually established by demonstration of seroconversion in paired sera or by demonstration of specific IgM antibodies (1). Enzyme-linked immunosorbent assay (ELISA) for IgM antibodies against these infections is highly sensitive and specific (6). The conventional single serum assays do not make a clear distinction between a recent primary and chronic infection. The tendency of specific IgM to persist for a long time even at high levels has been verified in several studies $(7,8)$. After its introduction in serodiagnosis of Toxoplasma-associated infections, the measurement of IgG avidity has proved to be a highly-useful procedure, especially in combination with conventional serological assays (9).

However, this pilot study was aimed at evaluating the possible usefulness of conventional screening of TORCH in females with $\mathrm{BOH}$ in eastern Nepal.

\section{MATERIALS AND METHODS}

\section{Study setting and design}

This pilot case-control study was carried out over a four-month period at a tertiary referral hospital in Nepal. 
Twelve women with $\mathrm{BOH}$ and a similar number of matched controls (without any $\mathrm{BOH}$ and previous normal pregnancies) attending our antenatal clinic were included in the study. Cases were selected depending on a previous history of having 2-3 pregnancy wastages, intrauterine deaths, preterm deliveries, intrauterine growth retardation, and unexplained early neonatal deaths.

Factors considered for selecting matched controls were age ( \pm 2 years), similar gravidity, same period of gestation in present pregnancy, and same number of livebirths opposed to bad obstetric complaints in the cases group. Detailed examinations and conventional laboratory investigations were carried out in both the groups. After taking consent from each woman, $3 \mathrm{~mL}$ of venous blood was collected in a container with strict aseptic precautions. The serum, thus, obtained was used for serological evaluation of TORCH infections. TORCH IgG and IgM antibodies were detected from the serum by ELISA test-kit (Calbiotech Inc, Canada) following the instructions of the manufacturer. The kits for detection of antibodies were based on sandwich ELISA method. Absorbance was taken at wavelength of $450 \mathrm{~nm}$, and results were calculated according to the instructions. TORCH antibody index was calculated by dividing the value of each sample by calibrator values. The antibody index of 1.0 or greater was considered positive for antibodies.

The results of the two groups (cases and controls) were compared (Table 1). Statistical analysis was not done to compare the results relating to the two groups due to a small number of cases and controls included in the study.

Ethical approval

The Ethical Committee of the Institute granted ethical clearance to the study.

\section{RESULTS}

Different presentations of $\mathrm{BOH}$ cases and matched controls with their TORCH status are shown in Table 1 , and seropositivity of TORCH agents in the two groups is shown in Table 2. Five cases showed mixed seropositivity. Mixed seropositivity was not found in any of the controls. A maximum number of $\mathrm{BOH}$ cases was found in females aged 18-24 years.

Ten (83.3\%) of the $12 \mathrm{BOH}$ cases and two (16.7\%) of the 12 healthy controls were serologically positive at least for one of the TORCH agents. The seropositivity rate in women with $\mathrm{BOH}$ was quite high compared to that in the normal healthy controls.
In the $\mathrm{BOH}$ cases, the seropositivity for $T$. gondii was $50 \%$, rubella virus 50\%, HSV-2 33.3\%, and CMV $8.3 \%$ whereas, in the control cases, the seropositivity for $T$. gondii was $16.7 \%$ only and that of the remaining ones was $0 \%$.

\section{DISCUSSION}

To the best of our knowledge, baseline data on seropositivity in the local population are not available from any part of Nepal. In the present study, T. gondii (50\%), rubella virus (50\%), HSV-2 (33.3\%), and CMV $(8.3 \%)$ were found in pregnant women with $\mathrm{BOH}$. These data are very high compared to those available from the neighbouring country (India) $(3,7)$. It might be due to the fact that the number of cases and controls included in the present study is very less, and, as such, it may not be reflect the true picture of TORCH infections. However, the difference between the two groups was quite significant numerically.

Although IgG of the samples was determined, the interpretation is mainly based on the value of IgM as paired sera were not tested.

Further, the cost of the whole TORCH-panel test being very high, most general population of an underdeveloped country, such as Nepal, cannot comfortably afford. By including vaccination against rubella virus (MMR vaccine) in the national immunization schedule, the incidence of congenital rubella can be reduced to a large extent. Moreover, this component can be deleted from the TORCHpanel investigations, thereby reducing their cost.

\section{Conclusions}

Based on the findings of the study, it is concluded that a previous history of pregnancy wastage and the serological reactions for TORCH infections during current pregnancy must be considered while managing $\mathrm{BOH}$ cases to reduce the adverse foetal outcome. Keeping consideration of the high cost of the test panel, selected tests (of the whole panel) are recommended on an individual case basis. Incorporation of rubella immunization into the national immunization schedule is recommended. Toxoplasma-associated infection can be prevented by educating the public about avoidance of ingestion of raw or insufficiently-cooked meat and poultry and keeping proper hygiene. An extensive study covering a large population should be conducted to know the seropositivity of TORCH agents and also to know the real status of these infections in $\mathrm{BOH}$ cases. 


\begin{tabular}{|c|c|c|c|c|c|c|c|}
\hline $\begin{array}{l}\text { Case vs } \\
\text { control }\end{array}$ & $\begin{array}{l}\text { Age } \\
\text { (years) }\end{array}$ & Parity & $\begin{array}{c}\text { Live- } \\
\operatorname{birth}(s)\end{array}$ & $\begin{array}{l}\text { Abort- } \\
\text { ion(s) }\end{array}$ & $\begin{array}{c}\text { Still- } \\
\operatorname{birth}(s)\end{array}$ & $\begin{array}{l}\text { Neonatal } \\
\text { death(s) }\end{array}$ & $\begin{array}{l}\text { TORCH } \\
\text { status }\end{array}$ \\
\hline Case & 24 & 1 & 0 & 1 & 0 & 1 & All negative \\
\hline Control & 26 & 2 & 2 & 0 & 0 & 0 & T. gondii positive \\
\hline Case & 22 & 1 & 0 & 1 & 1 & 0 & Rubella virus posi- \\
\hline Control & 21 & 2 & 2 & 0 & 0 & 0 & All negative \\
\hline Case & 29 & 2 & 0 & 0 & 1 & 1 & $\begin{array}{l}\text { T. gondii, CMV, } \\
\text { and HSV positive }\end{array}$ \\
\hline Control & 28 & 2 & 2 & 0 & 0 & 0 & All negative \\
\hline Case & 23 & 2 & 0 & 0 & 0 & 2 & Rubella virus posi- \\
\hline Control & 25 & 2 & 2 & 0 & 0 & 0 & $\begin{array}{l}\text { tive } \\
\text { All negative }\end{array}$ \\
\hline Case & 22 & 2 & 0 & 1 & 0 & 2 & $\begin{array}{l}\text { T. gondii and } \\
\text { rubella virus } \\
\text { positive }\end{array}$ \\
\hline Control & 24 & 3 & 3 & 0 & 0 & 0 & All negative \\
\hline Case & 20 & 1 & 0 & 2 & 0 & 1 & $\begin{array}{l}\text { Rubella virus and } \\
\text { HSV positive }\end{array}$ \\
\hline Control & 21 & 3 & 3 & 0 & 0 & 0 & All negative \\
\hline Case & 18 & 0 & 0 & 2 & 0 & 0 & $\begin{array}{l}\text { T. gondii and } \\
\text { rubella virus posi- } \\
\text { tive, HSV } \\
\text { positive }\end{array}$ \\
\hline Control & 20 & 2 & 2 & 0 & 0 & 0 & All negative \\
\hline Case & 24 & 1 & 0 & 1 & 1 & 0 & T. gondii positive \\
\hline Control & 25 & 2 & 2 & 0 & 0 & 0 & All negative \\
\hline Case & 30 & 3 & 0 & 0 & 0 & 3 & Rubella virus \\
\hline Control & 31 & 3 & 3 & 0 & 0 & 0 & $\begin{array}{l}\text { positive } \\
\text { All negative }\end{array}$ \\
\hline Case & 35 & 0 & 0 & 2 & 0 & 0 & All negative \\
\hline Control & 37 & 2 & 2 & 0 & 0 & 0 & T. gondii positive \\
\hline Case & 18 & 0 & 0 & 2 & 0 & 0 & $\begin{array}{l}\text { T. gondii positive } \\
\text { and HSV positive }\end{array}$ \\
\hline Control & 20 & 2 & 2 & 0 & 0 & 0 & All negative \\
\hline Case & 22 & 0 & 0 & 2 & 0 & 0 & T. gondii positive \\
\hline Control & 23 & 2 & 2 & 0 & 0 & 0 & All negative \\
\hline
\end{tabular}

\begin{tabular}{|c|c|c|c|c|}
\hline \multirow{2}{*}{ TORCH agent } & \multicolumn{2}{|c|}{$\begin{array}{l}\text { Seropositivity in BOH group } \\
(\mathrm{n}=12)\end{array}$} & \multicolumn{2}{|c|}{$\begin{array}{l}\text { Seropositivity in control group } \\
\qquad(\mathrm{n}=12)\end{array}$} \\
\hline & No. & $\%$ & No. & $\%$ \\
\hline Toxoplasma gondii & 6 & 50 & 2 & 16.7 \\
\hline Rubella virus & 6 & 50 & 0 & 0 \\
\hline Cytomegalovirus & 1 & 8.3 & 0 & 0 \\
\hline Herpes simplex virus 2 & 4 & 33.3 & 0 & 0 \\
\hline
\end{tabular}




\section{REFERENCES}

1. Turbadkar D, Mathur M, Rele M. Seroprevalence of torch infection in bad obstetric history. Indian J Med Microbiol 2003;21:108-10.

2. McCabe R, Remington JS. Toxoplasmosis: the time has come. N Engl J Med 1988;318:313-5.

3. Kapil A, Broor S. Primary cytomegalovirus infection in pregnant and nonpregnant women in India. Indian J Med Microbiol 1992;10:53-5.

4. Daftary SN, Chakravarti S. Obstetric disorder in pregnancy. Holland and Brews Manual of obstetrics. 15th ed. New Delhi: B.I. Churchill Livingstone, 1991:138.

5. Newton E. Diagnosis of perinatal TORCH infections. Clin Obstet Gynecol 1999;42:59-70.
6. Thapliyal N, Shukla PK, Kumar B, Upadhyay S, Jain G. TORCH infection in women with bad obstetric history-a pilot study in Kumaon region. Indian J Pathol Microbiol 2005;48:551-3.

7. Pinon JM, Thoannes H, Gruson N. An enzyme-linked immune-filtration assay used to compare infant and maternal antibody profiles in toxoplasmosis. J Immunol Methods 1985;77:15-23.

8. Del Bono V, Canessa A, Bruzzi P, Fiorelli MA, Terragna A. Significance of specific immunoglobulin $\mathrm{M}$ in the chronological diagnosis of 38 cases of toxoplasmic lymphadenopathy. J Clin Microbiol 1989;27:2133-5.

9. Hedman K, Lappalainen M, Seppaia I, Makela O. Recent primary toxoplasma infection indicated by a low avidity of specific IgG. J Infect Dis 1989;159:73640. 